Vlad Pojoga

Faculty of Letters and Arts, Lucian Blaga University of Sibiu

Sibiu, Romania

vlad.pojoga@ulbsibiu.ro

Laurentiu-Marian Neagu Computer Science Department, University Politehnica of Bucharest

Bucharest, Romania laurentiu.neagu@stud.acs.pub.ro

Mihai Dascalu Computer Science Department, University Politehnica of Bucharest Bucharest, Romania mihai.dascalu@cs.pub.ro

\title{
THE CHARACTER NETWORK IN LIVIU REBREANU'S ION: A QUANTITATIVE ANALYSIS OF DIALOGUE
}

Recommended Citation: Pojoga, Vlad et al. "The Character Network in Liviu Rebreanu's Ion: A Quantitative Analysis of Dialogue”. Metacritic Journal for Comparative Studies and Theory, 6.2, 2020:

https://doi.org/10.24193/mjcst.2020.10.02

\begin{abstract}
This study revisits what is widely considered "the first modern novel" in Romanian literature, Liviu Rebreanu's Ion, from a network theory perspective. Isolating the dialogue and quantitatively analysing the interventions of every character and their interactions in the fictional world, it provides a blueprint for the exploration of social and personal dynamics between characters. In recent years, rural literature in Romania has undergone a recontextualization process. Following in the footsteps of these approaches, our research provides the first character network of Ion and outlines who talks, how much, and to whom. It also explores how differences in social class influence
\end{abstract}


speaking time or the structure of the individual discourses, taking an in-depth look at the relationship between and roles of the two characters who talk most.

Key words: Romanian literature, digital analysis, character network, Liviu Rebreanu, quantitative analysis, dialogue extraction

\section{The Surrounding Voices}

If we break a text into its main functional units, single words, and then count these words, the results are usually predictable: at the front of the line, with most occurrences, are always connectors and proper names. If we take these two categories out of the equation and try to find links between the others, we might see the actual focus of the text. In Liviu Rebreanu's Ion, of all the words with more than 50 occurrences in the novel, two groups stand out: body parts (eyes, faces, hands, hearts, heads, mouths etc.) and dialogue operators (said, answered, shouted, mumbled, asked, etc. alongside verbs in the second person). Even though most novels narrated in the third person inherently possess a prominent semantic field of dialogue operators, it is also obvious that it augments the importance of who, when, and how much someone speaks by signalling the particular instance, especially given that spoken conversation comprises a mere $15 \%$ of the novel. Moreover, it is the only chance we get to hear anything from any character throughout the novel. Who is part of the conversation and who talks to whom is essential in determining the social status, complexity, and mobility of the characters.

Although being almost unanimously considered the turning point in the evolution of the Romanian novel (see Manolescu 577, where he calls Rebreanu "the creator of our modern novel"), the majority of the analyses published about Ion over the past century revolve almost exclusively around the "destiny" of the eponymous character and the concept of (rural) epic. That is when they are not concerned with matters of "style", which is a common target for reproach from critics (see Călinescu 732, among others). The "main" plotline of the novel published in 1920 is considered to be the one following Ion Glanetașu, and his constant struggle to choose between "the voice of land" and "the voice of love." Even if Ion talks, moves, and acts in a clearly defined fictional world, one purposely mimetic of the early 2oth century Transylvanian rural ethos, he manages to keep almost all of the metatextual spotlight on himself. The rest of the 
storyworld ${ }^{17}$ is somewhat blurred in criticism. This overwhelming focus on a single character has many possible explanations: from the change of title before publication (the original was The Dowry, the new one Ion) to the recurring debates around the Romanian peasant in the years before World War I (when two of the most influential directions in literature were sămănătorismul and poporanismul), right after the "invention of the peasant" during the $19^{\text {th }}$ century (Simion Cosma 165-191). Nevertheless, it has decisively been made the starting point for most critical inquiries into the novel after the publication of Rebreanu's 1940 non-fiction piece Mărturisiri. In the essay, he elaborates on the genesis of Ion and correlates the setting and existents of the storyworld with real places and people. He also highlights significant events, such as the kissing of the land and the unplanned pregnancy of an unmarried peasant girl that ends in terrible domestic violence at the hands of her father. But besides the detailed correspondences that become focal points for subsequent analyses, he also puts forward an intention, explaining how he "had the idea of augmenting the simple fight over land between peasants, which would've been too monotonous, with a secondary series of events, sometimes parallel, sometimes intermingled with the main ones, a series of events that look at the intellectual stratum from Ardeal [Transylvania - note ours] and, first and foremost, the family of the teachers and the family of the priests"18 (Rebreanu, Mărturisiri 249). This statement also seems to have provided a blueprint for the implicit hierarchization of events based on who participates in them. If it is Ion who participates (and the other peasants), they are "main" events. If it is the village intellectuals who participate, they are "secondary" events. But is that actually the case? Trying to shed light and provide a possible blueprint to answer this question, our research employs digital tools and narrative networks based on the quantitative analysis of dialogues between characters. We also try to explore the dynamics between existents and their position in the storyworld of Ion.

\footnotetext{
17 We use the term storyworld as defined by Marie-Laure Ryan in Story/Worlds/Media, 34-36. In her contribution, she lists as "components" of the storyworld the following entities: existents (characters), setting (space), physical laws (of the fictional world), social rules and values, events ("the causes of the changes of state").

18 "ideea de-a completa simpla ceartă între țărani pentru pământ, care ar fi fost prea monotonă, cu o acțiune secundară, când paralelă și când împletită cu cea principală, o acțiune care să privească pătura intelectuală din Ardeal și, în primul rând, familia învățătorească şi preoțească.” All of the quote translations from Romanian are ours, unless otherwise specified.
} 


\section{I.1. Revisiting the Rural in Romanian Literature}

On one hand, there is not much debate about the genre of Ion. Whether we choose to call it a rural novel, a "peasant novel" (Călinescu 731), a rural epic or an epic of the peasant (the "epic" is recurring in Lovinescu, Călinescu, Balotă, among others), Ion clearly revolves around characters from a rural Transylvanian community at the beginning of the $20^{\text {th }}$ century with most of the events happening in village of Pripas and its neighbouring villages. On the other hand, a series of studies and research results published in recent years have facilitated a reassessment of the rural in Romanian literature. When scholars decided to use quantitative instruments and distant reading as an analytical device to investigate Romanian literary production, and especially the production of the novel, unexpected results were uncovered. Although novel production and literary production were already being studied based on The Chronological Dictionary of the Romanian Novel (Terian, Big Numbers; Gârdan, The Great (Female) Unread) or the CIP Bibliography of the National Library of Romania (Terian, Istoria literară şi analiza cantitativă), the most significant enabler for large-scale analysis of the novel was The Digital Museum of the Romanian Novel. Comprising more than 500 novels published between 1844 and 1932 in two stages (Baghiu et al., MDRR 19 ${ }^{\text {th }}$ century; Baghiu et al., MDRR 1901-1932), the corpus made a series of new discoveries possible and quantifiable. For instance, an overview of the internal geography of the Romanian novel in the $19^{\text {th }}$ century shows that, contrary to expectations and previous appraisals, only around $25 \%$ of the total novels are placed in a rural environment (Baghiu et al, Geografia internă 29-43). The proportion remains roughly the same for the next period investigated, 1901-1932, at around 28-29\% (Modoc et al. 12-21). Even more so, in his in-depth analysis of the production of rural novel in Romania, Cosmin Borza inventories all the novels published between 1900 and 2000, reaching the conclusion that only around $7 \%$ of them can be categorized as "rural." The discrepancy in results stems from the inclusion criteria. Whereas Baghiu et al. and Modoc et al. included all of the novels where the action was taking place in a rural environment, Borza added two other prerequisites, arguing that a novel is "rural" only when "a. the protagonists belong to the peasant social class; $b$. the narrative's setting is the rural space; c. the literary conflict/themes are tightly bound to or typical of rural existence" 
(Borza 24). So how is it possible for such a small number of novels to become the focus of (and even determine the need for) an entire movement whose purpose was the "urbanization" of Romanian literature (Sburătorul)? Ștefan Baghiu and Vlad Pojoga, in their introduction to Ruralism and Literature in Romania, have found two possible explanations for the general perception that ruralism is over-represented in the literary production. First they argue that a "superficial" interpretation of the distribution of population in Romania, which underwent a slower urbanization process and thus had extensive rural population up until the second part of the $20^{\text {th }}$ century, led to a correlation between "the statistical reality" and the fictional spaces. Secondly, they suggest that the construction of the high-school Romanian canon, that includes seven writers of narrative fiction, only has two novels "set in an urban landscape" (Baghiu and Pojoga 14). Given that in Romania passing the Baccalaureate is a prerequisite for graduating high-school and enrolling in universities, the compulsory curriculum gives the impression that Romanian literature is overwhelmingly rural. Ion, having a central place in the already exclusive canon, could not have escaped this revisiting effort, and several studies published in 2019 and 2020 have done just that: from the intersectional analyses of Anca Parvulescu and Manuela Boatcă (See Parvulescu and Boatcă, The Inter-imperial Dowry Plot; Dis(Counting) Languages; The longue durée of Enslavement) to the zoopoetics approach proposed by Terian's 2019 "Liviu Rebreanu. Zoopoetics in a Rural Environment”. Furthermore, as recently as this month, at the $100^{\text {th }}$ anniversary of the publication of the novel, two articles urging the recontextualization and rereading of Ion were published by Costi Rogozanu and Mihai Iovănel in mainstream media. The former calls it "the most wrongly understood novel in Romanian literature" (Rogozanu), while the latter briefly approaches inequalities between characters in the fictional universe (Iovănel). The current study expands on these hypotheses and takes an in-depth look at the mechanics of the fictional world, trying to determine its actual social and power structure.

\section{I.2. Character Networks: A Brief Outlook \& Working Methodology}

The emergence of digital humanities and quantitative literary studies in the late $1990 \mathrm{~s}$ and early 2000s, facilitated by the appearance of a new medium, gave scholars the ability to process large amounts of text and data. Certain digital tools can almost 
instantly offer clues about word frequency, word associations, vocabulary density, sentence length, correlations between terms and many more. But all of these are, in one way or the other, matters of style. They do not account for character behaviour or movement, for plot analysis and do not offer clues in regard to intra-fictional world relationships. Network theory, on the other hand, can be the right instrument for such an endeavour. Essentially, the approach produces a network of nodes and edges, where the nodes are characters themselves, and the edges are interactions between them. If the nodes are rather fixed, the edges can be quantified in different ways, according to different methodologies. At the beginning of the 2000s, it was already used to map the characters in comic books (Alberich, Miro-Julia, Rossell) by the number of appearances in instalments. Franco Moretti, one of the most quoted scholars of digital humanities and the proponent of distant reading as a research method uses a version of it to explore the relationships between characters in Hamlet, but in his approach he is simply linking characters and does not account for the number of interactions. In recent years, it was used to identify character networks from various works, from popular fiction like Harry Potter and Twilight (Bonato et al.) to Les Miserables (see a brief compilation of visual representations in Taylor). In Romania, network theory was scarcely referred to until now, with the notable exceptions of Emanuel Modoc when charting the links between the nodes of the historical avant-garde (see Modoc, Internaționala periferiilor) and Vlad Pojoga when suggesting the use of "network" as a centerpiece term for the vocabulary surrounding digital narrative literature (Pojoga, The Change of Medium). Network theory has also been used in conjunction with other computational analyses, such as those related to the digital measurment of style (stylometry, see in this issue Modoc and Gârdan 48-63). Quantitative surveys of dialogue are also used in non-academic publications to identify speakers by gender in popular movies (for an analysis of about 2000 movie screenplays see Anderson and Daniels). The purpose of this article is not to provide a state of the art on character networks (an in-depth methodology state of the art on the extraction and analysis of fictional character networks can be found in Labatut and Bost), but rather to propose a new way of reading and understanding the fictional dynamics of a canonical novel from Romanian literature in order to point out some useful instruments mainly for ideological readings and plot analysis. 
Our data gathering and processing involved several steps. To start, we worked with a novel, which is substantially different in any case from a play (Moretti) or movie script (Anderson and Daniels), in that it has no clear textual indices before a dialogue line. To make matters even more complicated, we worked with the Romanian version of Ion, and dialogue in Romanian is not even delimited by fixed symbols, as it is in English (by inverted commas). Because our analysis focused on a single text, and thus does not include a massive number of words (around 150,000), we decided to manually tag the dialogue and assign speakers to every line of spoken interventions based on textual clues rather than use an algorithm (as the ones in Labatut and Bost). Given the high volatility of the narratorial interventions in (and between) dialogue lines ${ }^{19}$, we considered manual tagging the method least prone to errors. Our tagging excluded all the aforementioned interventions by the narrator. For instance, if a dialogue line looked like this: "- Nimic, murmură flăcăul liniştit! M-am răcorit oleacă...” ['Nothing,' Ion murmured quietly. 'I just cooled my fever . . .'] $(38,35)$, it was tagged as "<speaker name="Ion" $>-$ Nimic, $</$ speaker $>$ murmură flăcăul liniştit! <speaker name="Ion" $>$ M-am răcorit oleacă...</speaker $>$." Once the exchanges were tagged, we proceeded with processing the data in two steps: we extracted the number of words, sentences and interventions of every character and then we quantified the "spoken" interactions/exchanges by using a proximity algorithm. To further elaborate on our example, it contains 4 words, 2 sentences, and 2 interventions. Because of the nature of our annotations, every narratorial interference, no matter how short, generates another intervention. Besides this, for every dialogue line between two characters, we increased the weight of their relationship by one point. From here on, we processed the resulting data to obtain visualizations either through HTML (using the templates provided by amCharts, in Fig. 1, 2, 3) ${ }^{20}$, Tableau (Fig. 8) or Gephi (for the networks in Fig. 4, 6, 7) ${ }^{21}$.

\footnotetext{
19 They can vary from one word to several dozens.

20 https://www.amcharts.com/

${ }^{21}$ For other tools for the digital analysis of the Romanian novel, see Pojoga et al, Digital Tools; for visualisations of quantitative analyses based on The General Dictionary of Romanian Novel and focused on authors, not fictional worlds, see Neagu et al. and Toma et al.
} 


\section{METACRITIC JOURNAL FOR COMPARATIVE STUDIES AND THEORY 6.2}

\section{The Voices of Characters}

The latter part of our article focuses on the visual presentation of our results and their analysis, trying to explore a. who are the characters that speak; b. how much they speak; c. how many sentences they utter (if correlated, b. and c. result in an estimate of the average sentence length for each character); d. how many interventions they have (as explained in section I.2); d. who they speak to; e. how the ensuing character network looks like; f. how social class and gender influence who speaks and in what manner; $f$. what the dynamics between characters who speak the most are; g. if there are any irregularities or contradictory characters.

\section{II.1. Who Speaks and How Much?}

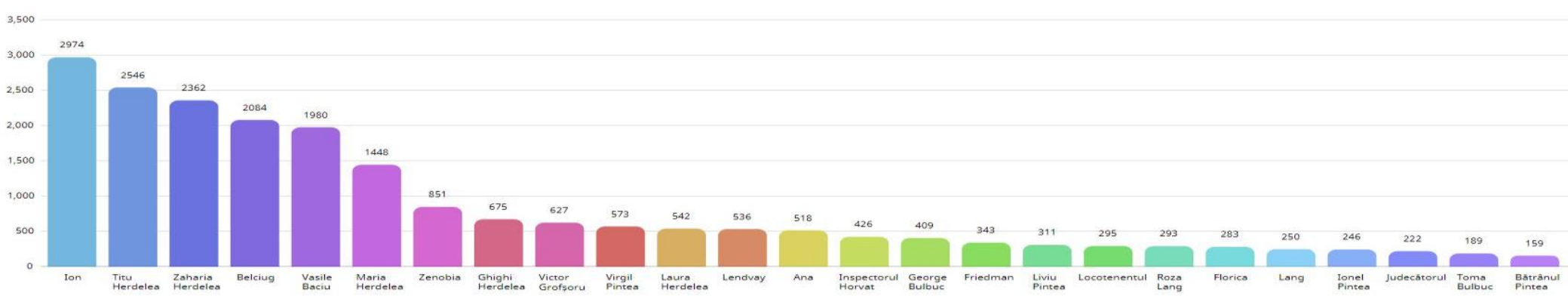

Figure 1. Number of words per character

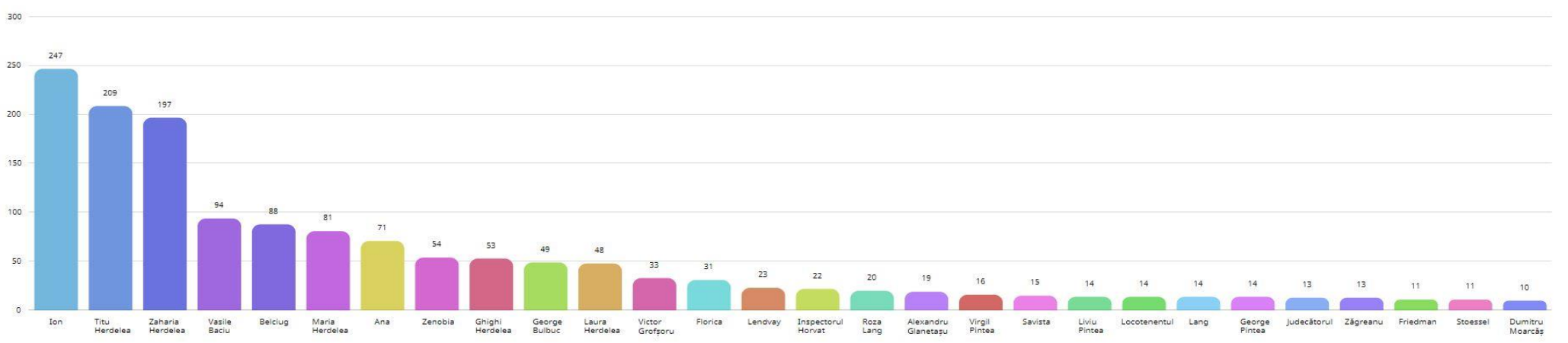

Figure 2. Number of sentences per character 


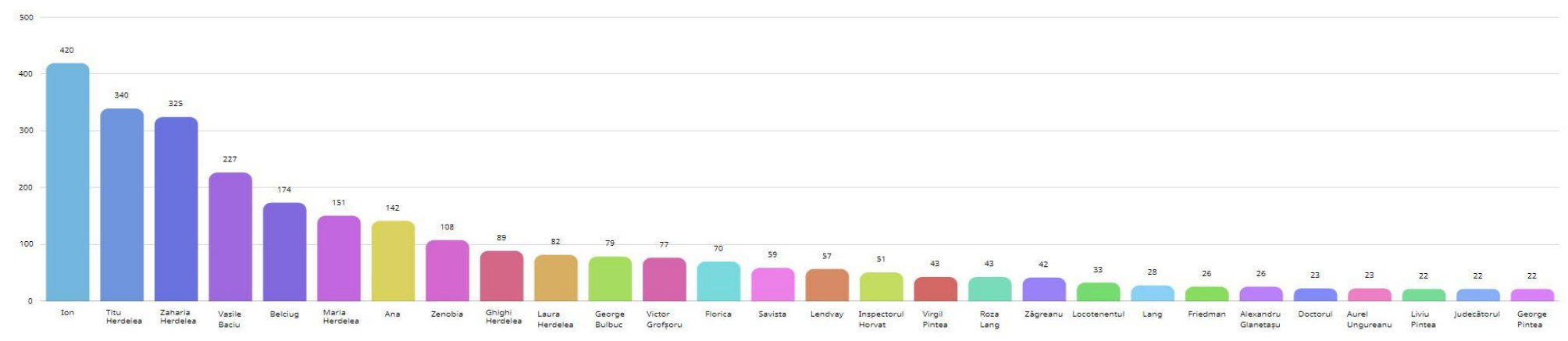

Figure 3. Number of interventions per character

From the most basic quantifiers we extracted (Words/Character - Fig. 1; Sentences/Character - Fig. 2; Interventions/Character - Fig. 3), we can already provide some general insights about the dialogue in Ion. If we correlate the three categories, we clearly see that Ion, Titu Herdelea (the teacher's son), and Zaharia Herdelea (the teacher) dominate the speaking time. Even though in terms of number of words the difference does not seem that substantial, but rather progressive, if we take into account sentences and interventions, they clearly pull ahead (with averages for the three categories of around 1,210 - Ion, 1,030 - Titu, 960 - Zaharia Herdelea, while the fourth and fifth characters in our classification, Belciug (the priest of the village) and Vasile Baciu (a rich peasant, Ion's future father-in-law), only have averages of around 780 and 770). Additionally, in terms of number of words, male characters dominate the best represented positions, with 7 of the first 10 characters who speak most being male (we will return to this in section II.3, taking into account all characters, not only the 10 best represented). Also, we can observe some anomalies between the three "leaderboards", the most striking being, probably, the case of Ana (peasant woman, daughter of Vasile Baciu and future wife of Ion), who is $13^{\text {th }}$ in terms of words spoken, but $7^{\text {th }}$ in both sentences uttered and interventions. At the opposite end of the spectrum is Belciug, who speaks more words than Vasile Baciu, but in less sentences and interventions. In a similar manner, minor characters that only appear sporadically and thus have a limited number of interventions, but even so manage to utter more words than characters generally perceived as more "relevant" to the plot. ${ }^{22}$ Moreover, Alexandru Glanetaşu,

${ }^{22}$ See, for instance, the cases of lawyers Victor Grofşoru and Lendvay and doctor Virgil Pintea, the brother of George Pintea, Titu's brother-in-law'. 
Ion's father, does not even appear in the first graph (that contains the most prominent 27 characters by number of words spoken).

But probably the most fruitful insight we can draw from the first set of graphs comes to light if we compare the total number of words spoken by Ion and his close family (his parents, Zenobia and Alexandru Glanetaşu, his wife, Ana, and his father-inlaw, Vasile Baciu) with the total number of words spoken by the family of the teacher, Herdelea (Zaharia, Maria, Titu, Laura, and Ghighi). The results are, surprisingly, given the critical preview we did in the first section of this essay, in favour of the teacher's family by roughly 1,000 words. This difference lays the groundwork for the broader analysis we will provide in section II.3 and suggests from the start that the group of characters who talk most might not be the ones we expect, and even though Ion talks the most, his "circle" does not.

\section{II.2. Who Speaks to Whom?}

Before delving into its meanings, the character network in Fig. 4 needs some further explanations in terms of its generation. After quantifying the interactions between characters as described in section I.2, we processed the data through Gephi. The software, when creating the network, takes into account all the involved factors and quantified the importance and position of the nodes (characters) in the network based on both the number of interactions and the number of interactors (i.e., the number of nodes/characters they are linked to). Therefore, although Ion leads in words, sentences, and interventions, Titu Herdelea's node is significantly larger since he interacts with more characters (about $25 \%$ of the total number of characters in the novel to Ion's $20 \%$ ). Another feature of Gephi is that it automatically creates micro-communities of nodes and we color-coded those micro-communities to make the graphic representation clearer. With that in mind, we will now expand on the main insights the network offers. 


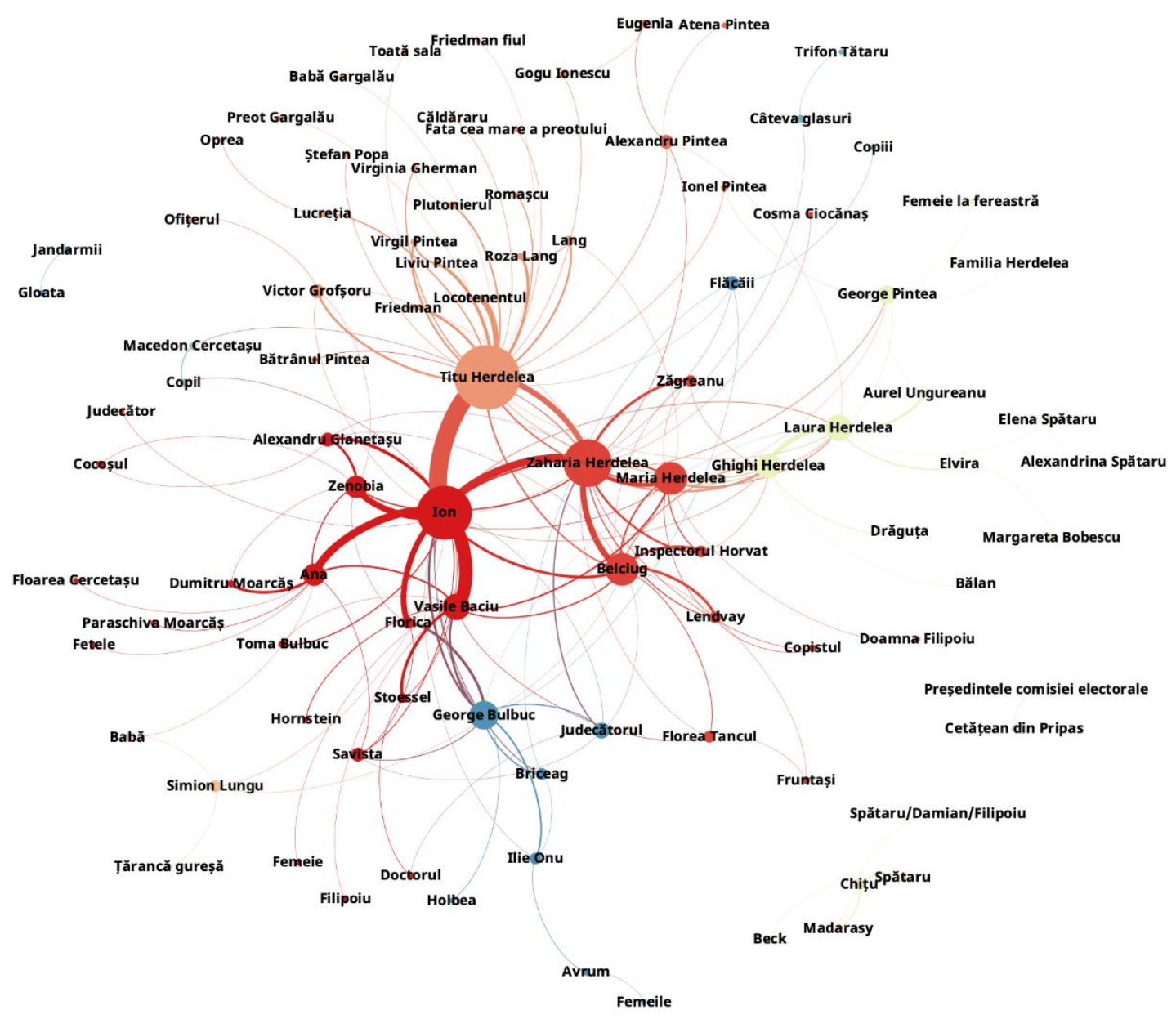

Figure 4. Character Network of Ion by Liviu Rebreanu

\section{a. The World of the Village}

The character network is, in all ways, a faithful representation of the fictional world of Pripas. It appears, from the very start, to be in accordance with Cosmin Borza's assertion that "the ancestral, mythical village becomes a credible rural community" (Borza 30), in that it is complex, stratified, and closely-knit at the centre. At the core of the network is the trio already identified in section II.1, but which one(s) of Ion, Titu Herdelea, and Zaharia Herdelea and how are closer to the "rural community"? We can clearly see, even from the colors of the network, that if we choose "the life of the village" 
as a reference point, Ion, Zaharia Herdelea, and not unsurprisingly, Belciug, the priest, are the points of convergence. Titu Herdelea, although very well connected to Ion and his own family, is otherwise just loosely linked to the rest of the village. If we go even further and try to figure out the second concentric circle of the village, we clearly see two main clusters inside the village, the peasants - grouped around Ion and his family, as well as the other prominent young peasant, George Bulbuc - and the village intellectuals - grouped around the Herdelea family and Belciug. There is no individual peasant, rich or poor, assigned to the village intellectuals' side, and the only non-peasants on Ion's side of the network are a notary and his aide, alongside doctors that come to tend to Petrișor (Ion and Ana's son) or to check Ion's dead body. And even then, the notary, when temporarily "inserted" into the actual home of the peasants to certify Ion's death, tells the doctor and the judge "We could draft the papers at the mayor's office, if you like. It's more comfortable and cleaner" (390)23, clearly indicating his repulsion. One other essential detail brought forward by the character network is that only male peasants (Ion, George, Ilie Onu) interact with the Roma musicians Briceag and Holbea, and in quite a violent way, for that matter, which suggests their extreme marginality (for an expanded analysis, see Parvulescu and Boatcă, The longue durée of Enslavement). Therefore, although perceived as a single unit, the world of the village is in itself clearly divided along social status lines, that actually make wealth futile, because not even the richest of peasants (Toma Bulbuc, Vasile Baciu, or their children) manage to break into the "other" side of the character network. It seems a world shaped in accordance to Maria Herdelea's position at the beginning of the novel, when the narrator says she "would never, for the life of her, have tolerated her daughter mixing with the peasants." (21). ${ }^{24}$

\section{b. Strong and Loose Edges}

Another inference we can make from the character network concerns edges. We can observe how the strongest (thickest) edges, designating the most lines of dialogue exchanged between two characters stem from Ion's node. He has, without question, the

\footnotetext{
23 "Dacă doriți, putem face actele la primărie, unde-i mai comod și mai curat..." (411). All of the quotes from Ion in English are taken from A. Hillard's translation (1965).

24 “care n-ar fi îngăduit nici în ruptul capului ca fata ei să se amestece printre țărani” (22).
} 
most meaningful exchanges with a handful of characters (Titu, Vasile Baciu, Ana, Zaharia Herdelea and Zenobia), and these exchanges are all part of (and constitute) the so called "main" plotline. Interestingly enough, the number of interactions between Ion and Ana is equal to Ion's interactions with Zaharia Herdelea, and significantly smaller than the number of interactions between Ion and Titu or Vasile Baciu. Zaharia Herdelea himself has rather thick edges with four characters (Ion, Titu, Belciug, and Maria Herdelea), but substantially slimmer ones to his two daughters. A thicker edge can also be seen in the second concentric circle, between the two Herdelea daughters, Laura and Ghighi. The slimmest of edges are, of course, at the margins of the network, between characters that only appear once.

\section{c. Micro-communities, Exceptions and Contradictions}

There are also multiple micro-communities, either isolated (see, for instance, the oneline interaction between the president of the Electoral Commission and a citizen from Pripas or the four-character network of Spătaru, Chițu, Madarasy, and Beck25) or part of the main network (Ghighi and Laura Herdelea, the teacher's daughters, have their own micro-comunnity, which contains both of Laura's suitors, Aurel Ungureanu and George Pintea - her future husband - and several girlfriends from the nearby town). The largest such sub-community is Titu Herdelea's, but we will discuss it in section II.4. We also have a single interaction between two collective characters "The Gendarmes" and "The Crowd," that happens during election day.

The most notable exception is Alexandru Glanetaşu, Ion's father, who speaks unusually little for a character so close to the core of the network. Even though his position in the narrative (as father of the protagonist) should enable him to play a bigger role in the character network, he engages in dialogue with only five characters, one of whom, peculiar as it might sound, is the family rooster (the others are Ion, Zenobia, Belciug and Zaharia Herdelea). The most likely explanation for this situation is that he is presented from the very beginning as being "womanly," and "lucky" to be with Zenobia, "a woman like a man." Throughout the novel, he is pictured as being weak. In the social

\footnotetext{
${ }^{25}$ Spătaru is a professor, Chițu a state official, Madarasy a forester and Beck a banker who at the time is a candidate for office. They are all connected through Chițu, but in different scenes - Spătaru and Madarasy at a going out, in the tavern, and Beck on election day.
} 
universe of Ion, apparently anything can be forgiven, from horrific domestic violence (Vasile Baciu) to public violence (Ion) to theft (Ion) to adultery (Titu, Ion, Florica), but weakness in a male character cannot.

The biggest contradiction of the character network is, by all standards, Ana. Considered by many critics a central character (Manolescu even calls her one of "the protagonists of Ion," 582), she talks extremely little and mainly with one other character, Ion. Most of her dialogue is short and the scene right after Ion beats her, in which she is "shushed" by another peasant woman stands out: "There now child! Don't cry any more. Hush! you must bear everything in silence, for God has willed it that women shall suffer. Hush, now! Hush!" (236). This is how a seemingly central character such as Ana can have the second thickest edge with an episodic character, a peasant who appears only two times in dialogue throughout the text (exchanging one line with Zenobia earlier in the novel), Dumitru Moarcăș. Moreover, although she utters many sentences in comparison to other characters, her number of words per sentence average is abysmal (3.7), in line with minor and collective characters who only appear once or twice. For comparison, other words per sentence averages of characters with similar ages and central positions in the network place Ghighi Herdelea at 7.6, Ion at 7.1, Titu at 7.5, and Laura Herdelea at 6.6. Therefore, Ana is a marginal character in the dialogue network, extremely underrepresented in speaking time, in contrast with the major role she plays in the plot.

\section{II.3. Quantifying Social Class and Gender}

Given that we have already explored individual relationships between characters and emphasized the clear demarcations between the two communities found inside the village (peasants and intellectuals), this part of our essay aims to further define social boundaries and relationships between what we will from now call social tiers. E. Lovinescu, in his brief description of the social categories in Ion, suggests that "the social life of Transylvania, which, although enclosed in a village-cell, is pictured in its full stratification, from vagabond to electoral candidate and the ranks of the Hungarian 
administration" (Lovinescu 310). ${ }^{26}$ We will now create demarcations for social tiers as they are perceived in the fictional world. Our numeration goes from 1 (closest to land and village) to 5 (farthest from the village). Hence, social tier 1 consists of peasants -24 characters, including Ion, Vasile Baciu, Zenobia, Ana, George Bulbuc, Florica, Toma Bulbuc, Alexandru Glanetaşu and others. Social tier 2, as already separated both by Rebreanu (Mărturisiri), and in a quite classist way by Călinescu ("on a higher step of consciousness is the existence of teacher Herdelea's family," 732), ${ }^{27}$ includes teachers, priests, their families, alongside episodic characters such as the mayor, for a total of 21 characters. Social tier 3, the tier of "mediators" (lawyers, doctors, notaries, accountants, high-school professors, and other "city people") has an unexpected number of speaking characters, 32. We included all state officials in social tier 4, from officers to judges to high clergy to the inspector, and 10 characters turned out to belong to this tier. Finally, tier 5, the one of elected officials (members of parliament) consists of only two characters, representative Gogu Ionescu and his wife, Eugenia. Naturally, since collective characters or unnamed characters are involved, around 30 characters could not be included in any tier. Also, gender-wise, 30 characters are female, 68 are male, 16 are collective, and 4 are non-human/non-specified (including a rooster).

In terms of aggregated results, the characters speaking time distribution on tiers (from 1 to 5 ) is approximately: $34 \%, 45.5 \%, 14 \%, 6 \%$, and $0.5 \%$. In terms of gender, female characters speak $22 \%$ of the total speaking time, whereas male characters speak $77 \%$ (the others speaking roughly $1 \%$ together). Before taking a closer look at other parameters, we can without doubt state that villagers talk most in Ion (around 80\% of the total talking time), that we have a clear gender gap in terms of talking time, and somewhat ironically given their relegation to the background in terms of critical focus, village intellectuals talk more than peasants (and by quite a lot given the distribution of the speaking time). Therefore, even if unanimously considered a rural novel "organized around a central figure, Ion" (Lovinescu 310), ${ }^{28}$ it is not the peasants who speak most of the time, but the village intellectuals. Thus, and because we are dealing with a third person heterodiegetic narrator who was hailed by many early critics for presenting the

\footnotetext{
26 “viața socială a Ardealului, care, deși închisă în celula unui sat, este zugrăvită în întreaga ei stratificație, de la simplul vagabond până la candidatul de deputat și la mediul administrației ungurești."

27 "pe o treaptă mai înaltă a conștiinței se petrece existența familiei învățătorului Herdelea."

28 "romanul se organizează, totuşi, în jurul unei figuri centrale, Ion.”
} 
fictional world without much interference, the voice of the village is heard mainly through the voice of the intellectuals in the village, pictured as "superior" in the fictional universe. The critical focus on Ion's personal drama and its subsequent mythologization blurs the actual image of the village: one in which, for instance, the main character does not (although owning a piece of land) participate in the political life of the village at all, he does not have any sense of collective identity, he only exists at an individual level, concerned only with his personal goals.

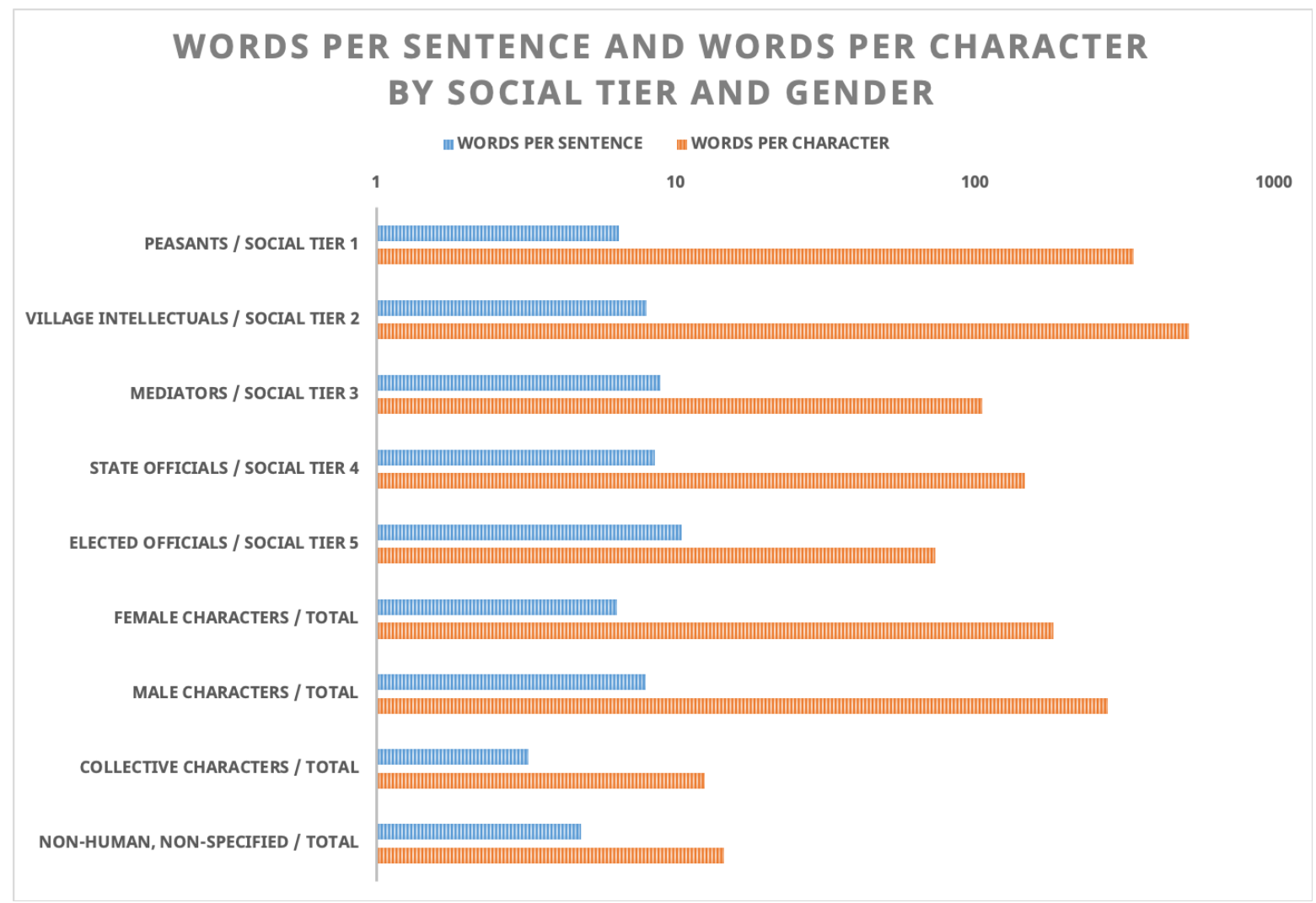

Figure 5. Word distribution according to social tier and gender

The characters are without a doubt "tightly dependent on clearly defined historical, socio-cultural, economical, and ideological realities" (Borza 30), and these realities are easily observed in Fig. 5, where we calculated the average number of words per sentence and words per character for every social tier and gender. Besides the obvious results that reinforce the hypotheses already advanced, we can also see that not only make characters talk substantially more than women characters, but the average male character talks more than the average woman character (an underrepresentation of an 
underrepresentation). Moreover, the average number of words per sentence for every tier seems to go up as the characters occupy higher positions in the fictional world - in the logic of the fictional world, social status is closely tied to speaking complexity, thus rendering the aforementioned progression.

The last, but not least element that we want to bring into question is movement between social tiers. Terian, in his "pseudo-Darwinist" study of Ion, has put forward the idea that "According to the rural worldview, they [the characters] will never succeed in transcending their condition" (46). The exception of Maria Herdelea, who was a peasant and married a teacher, is somewhat illusory and not expanded upon, and, as we have already shown, she is drastically against her daughters even dancing with peasants. Although we agree with Terian's assertion in the case of Ion, we need to expand it and include the idea of hope. Yes, there is no real advancement from one social tier to another in Ion, and every character seems the prisoner of its own social tier, but they usually hope and even try to transcend their conditions. Victor Grofşoru (lawyer, tier 3) hopes to become an elected representative (tier 5), Titu Herdelea (tier 2) hopes to become a journalist or published poet (tier 3) and move to the city, Laura Herdelea (tier 2) wants at first to marry a doctor (tier 3), but none of the peasants hope any such thing. Ion always looks up to Titu or Zaharia, asking for their council, but never even thinks of marrying one of the teacher's daughters. Whereas exponents of higher social tiers have at least will or actively try to exceed their own social status, peasants are portrayed as not even having that mental representation of advancement through social tiers.

\section{II.4. Ion vs Titu: Sociability and Mobility}

The last part of our analysis will briefly take into account two factors, sociability and mobility, applying them to the characters who talk most, Ion and Titu. On one hand, we assess sociability by looking at the number of characters that one specific character interacts with and their position in the network. On the other hand, mobility quantifies the places where characters talk and how much they talk in those places.

In terms of sociability, we made the same exercise Franco Moretti Does (Network Theory, Plot Analysis), and removed in turn Ion and Titu from the character network. The results (Fig. 6 for Ion and Fig. 7 for Titu) show a clear family (Ion) vs society (Titu) opposition. We can observe that, in the case of Ion, because most of his interactions 
occur at the level of his own family or village community, the network remains roughly unchanged, with a single character being disconnected: a judge. In the case of Titu, however, we lose more than 15 characters from the network, because he is their only link to the rest of the characters. In terms of mobility, Fig. 8 shows Ion uttering more than 95\% of his words in Pripas and saying one or two lines in three other places (Jidovița, Armadia, and Bistrița). Although he does make more trips to Jidovița and Armadia, they are related by the narrator, not including any "active" scenes. At the polar opposite is Titu, who utters less that $50 \%$ of his words in Pripas, speaking in 8 other places, including near Cluj (in the train) or in the far-away Sibiu. Titu's mobility is tightly related to his high sociability - because only he has access to certain spaces that are "outside" Pripas, only he gets to interact with several episodic characters, and that gives him his central place in the network. Through Titu (and almost only through Titu) we are shown more than just Pripas.

Revealing for this dynamic, and both for the sociability and mobility of Titu in comparison to Ion is the final dialogue they have:

'I hear you're leaving us for good, master Titu?' / 'I'm setting out to find my place in the world!' returned Titu earnestly. 'Time passes and a man must accomplish something in his life; if he fails, he doesn't deserve to live. Isn't that so?' / 'Yes, master Titu, you are perfectly right!' Ion said. 'May God keep you healthy and grant you good luck wherever you go, for you've been a fine and a decent man indeed!' (369). ${ }^{29}$

While Titu "sets out to find his place in the world", Ion, who had just lost his wife and child and was going to soon lose his life, admiratively approves of Titu's decision. If it is as Lucian Raicu suggests, and "the Herdelea family lives the epic of everyday life and Ion is the hero of a tragic epic" (79)30, then an "everyday epic" of an exponent of a higher social tier is much broader in terms of sociability and mobility than a "tragic epic" of a lower social tier.

29 “- Am auzit că vrei să pleci departe, domnişorule? / - Mă duc şi cu să-mi găsesc un rost în lume! răspunse Titu serios. Anii trec şi omul trebuie să facă ceva în viaţă, altfel nu-i vrednic să trăiască... Nu-i aşa ? / - Aşa-i, domnişorule, vezi bine că-i aşa! zise Ion. Apoi să te ducă Dumnezeu sănătos şi să-ţi dăruiască noroc pe unde-i umbla, c-ai fost tare de omenie!" (388).

30 "familia Herdelea trăiește epopeea vieții curente, Ion, dimpotrivă, este eroul unei epopei tragice." 


\section{THE CHARACTER NETWORK IN LIVIU REBREANU'S ION}

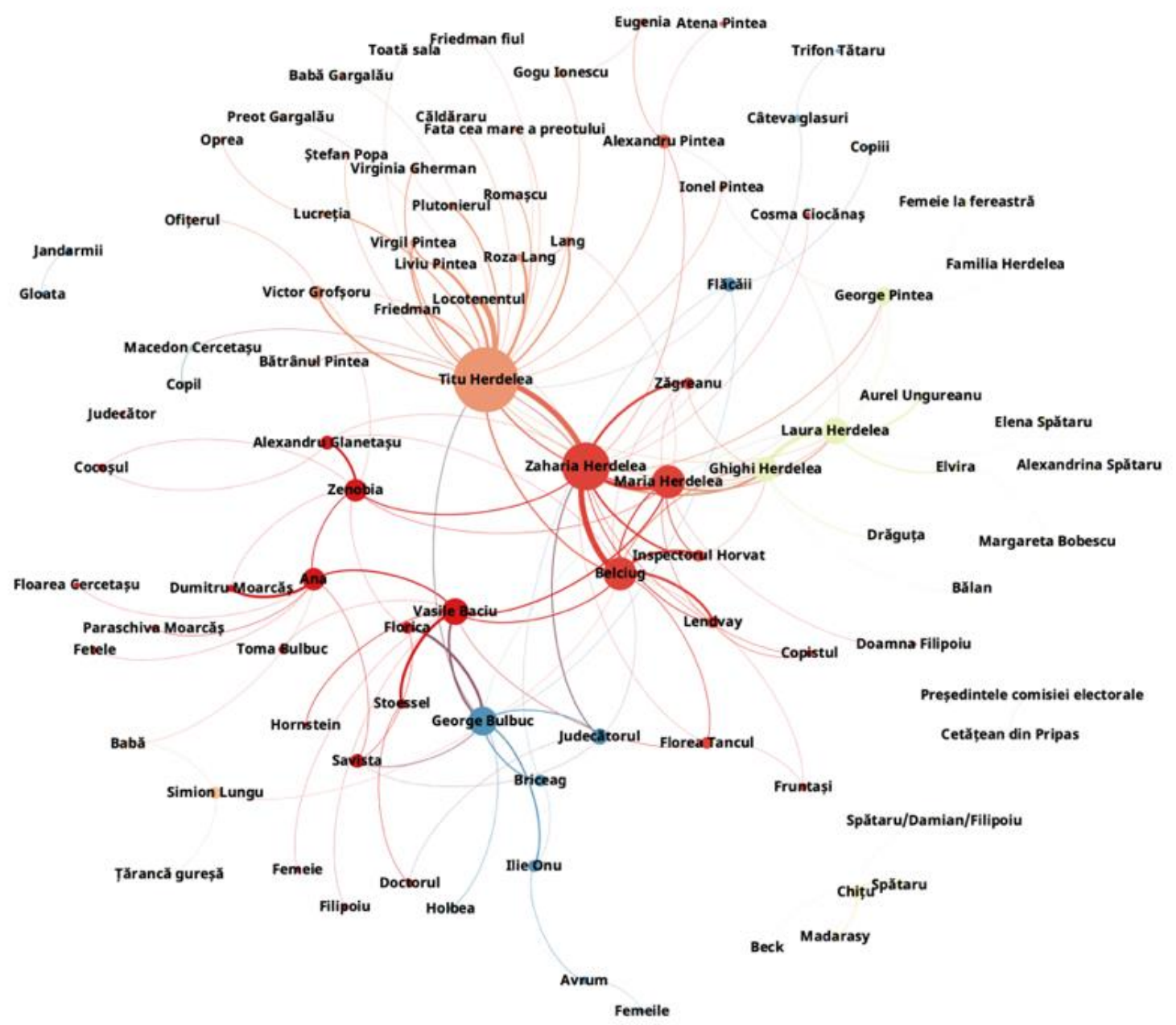

Figure 6. Character Network of Ion by Liviu Rebreanu without Ion 


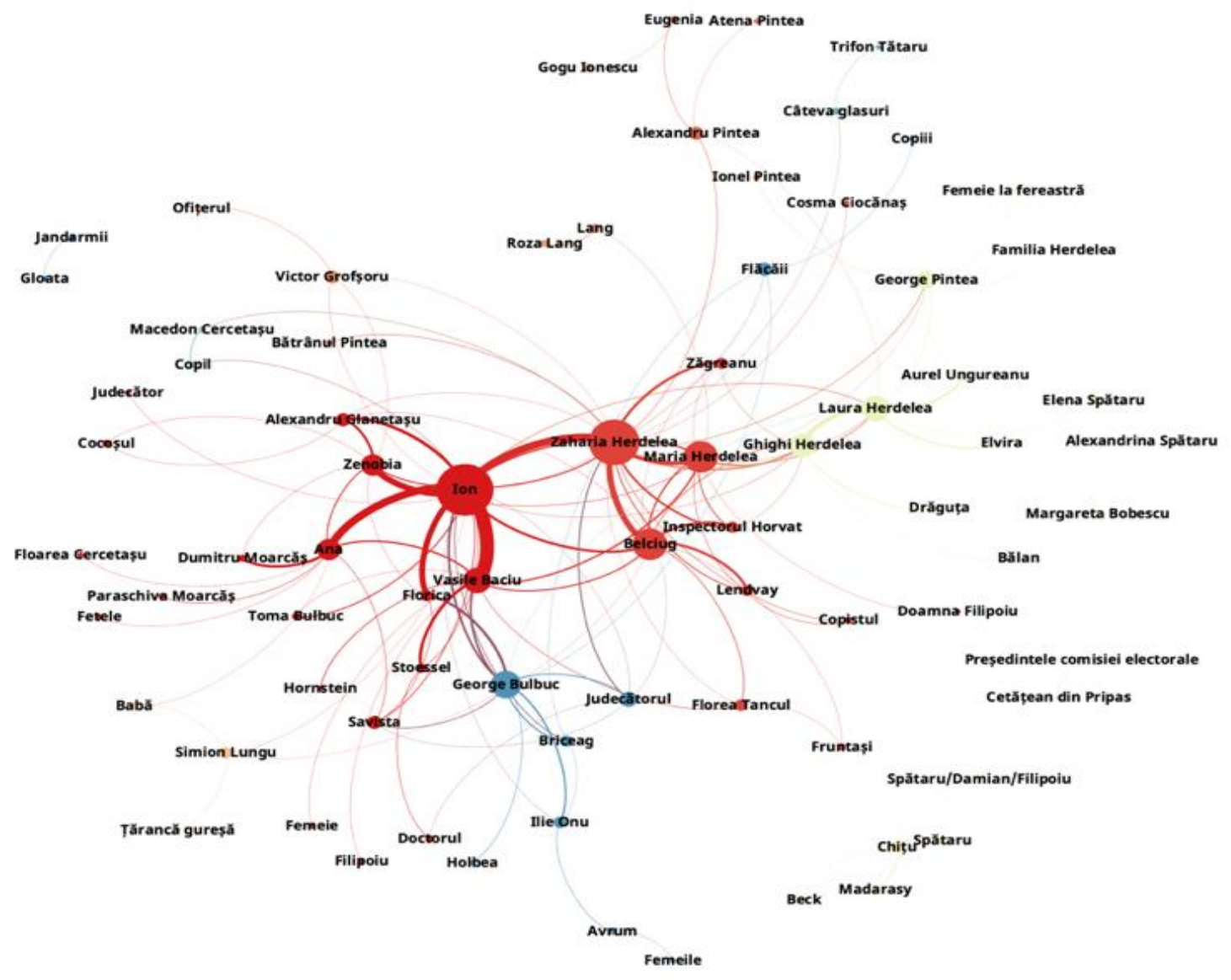

Figure 7. Character Network of Ion by Liviu Rebreanu without Titu Herdelea

In conclusion, our quantitative analysis of dialogue in Ion offered numerous insights, of which the most relevant seem to offer a fruitful groundwork for a reassessment of the positions of characters in the novel. Firstly, village intellectuals actually talk more than peasants in what is a rural novel (45.5\% to $34 \%$ ). Secondly, Titu Herdelea is a more important node in the network than Ion in terms of sociability and mobility. Thirdly, dialogue lines get more complex when in accordance to the social tier of the character who utters them. Fourthly, the strongest link is between Ion and Titu Herdelea. And last, but not least, characters perceived as central, such as Ana and Alexandru Glanetaşu, play minor roles in terms of speaking time and relevance for the dialogue network. 


\section{THE CHARACTER NETWORK IN LIVIU REBREANU'S ION}

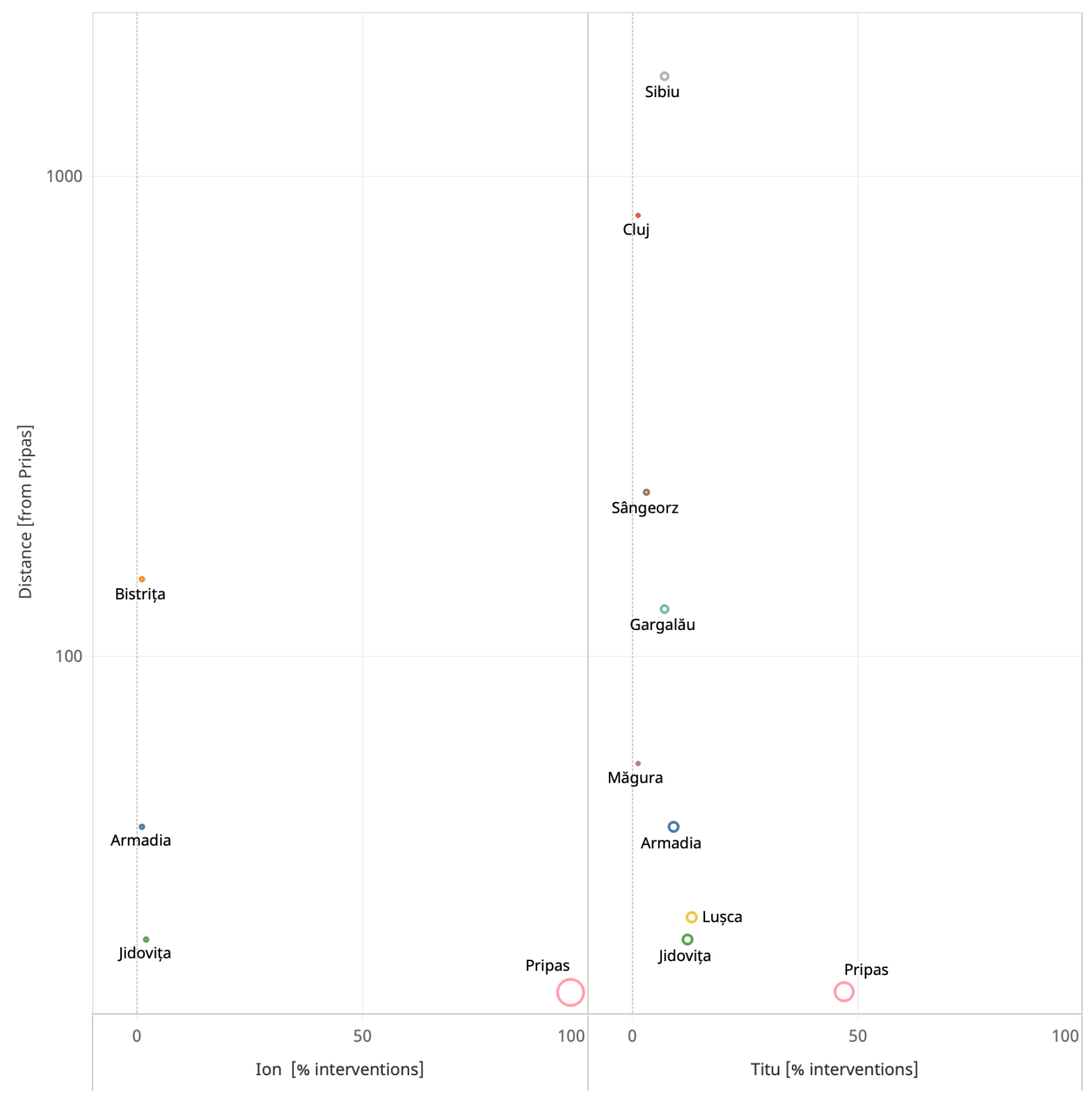

Figure 8. Ion and Titu: Where They Speak and How Much 


\section{Acknowledgement:}

This work was supported by a grant of the Romanian Ministry of Research and Innovation, CCCDI - UEFISCDI, project number PN-III-P1-1.2-PCCDI-2017-0821/ INTELLIT, within PNCDI III.

\section{Works cited:}

Alberich, R, J. Miro-Julia, F. Rossello. "Marvel Universe looks almost like a real social network," http://arxiv.org/abs/cond-mat/o202174v1.

Anderson, Hannah, Matt Daniels. "Film Dialogue from 2000 screenplays, Broken Down By Gender and Age." The Pudding, April 2016, https://pudding.cool/ 2017/o3/film-dialogue/.

Baghiu, Ștefan, and Vlad Pojoga. "Ruralism and Literature in Romania. An Introduction.” Ruralism and Literature in Romania, edited by Ștefan Baghiu, Vlad Pojoga, Maria Sass, Peter Lang, 2019: 13-20.

Baghiu, Ștefan et al. "Geografia internă a romanului românesc în secolul al XIX-lea." Transilvania, no. 10, 2019: 29-43.

Baghiu, Ștefan et al. "Geografia romanului românesc (1901-1932): Străinătatea” [The Geography of the Romanian Novel (1901-1932): Spaces from Abroad]. Transilvania, no. 10, 2020: 1-11.

Baghiu, Ștefan et al. Muzeul Digital al Romanului Românesc: secolul al XIX-lea. Complexul Naţional Muzeal ASTRA, 2019. https://revistatransilvania.ro/mdrr, accessed 15 November 2020.

Baghiu, Ștefan et al. Muzeul Digital al Romanului Românesc: 1901-1932. Complexul Național Muzeal ASTRA, 2020. https://revistatransilvania.ro/mdrr1901-1932, available from 15 December 2020.

Balotă, Nicolae. De la Ion la Ioanide. Eminescu, 1974.

Bonato, Anthony et al. "Mining and Modeling Character Networks." Algorithms and Models for the Web Graph: 13th International Workshop, WAW 2016, Montreal, QC, Canada, December 14-15, 2016, Proceedings, edited by Anthony Bonato, Fan Chung Graham, Paweł Prałat, Springer, 2016. 
Borza, Cosmin. "How to Populate a Country. A Quantitative Analysis of the Rural Novel from Romania (1900-2000)." Ruralism and Literature in Romania, edited by Ștefan Baghiu, Vlad Pojoga, Maria Sass, Peter Lang, 2019: 21-39.

Călinescu, G. Istoria literaturii române de la origini până în prezent. Minerva, 1986.

Gârdan, Daiana. "The Great (Female) Unread. Romanian Women Novelists in the First Half of the Twentieth Century: A Quantitative Approach.” Metacritic Journal for Comparative Studies and Theory 4.1, 2018, https://doi.org/10.24193/ mjcst.2018.5.07.

Iovănel, Mihai. "100 de ani cu Ion de Liviu Rebreanu.” Scena9, December 7, 2020. Online: https://www.scena9.ro/article/roman-ion-liviu-rebreanu-10o-ani.

Labatut, Vincent, and Xavier Bost. "Extraction and Analysis of Fictional Character Networks: A Survey.” ACM Computing Surveys 52(5): 89, 2019, https://doi.org/ $10.1145 / 3344548$

Lovinescu, E. Opere II. Istoria literaturii române contemporane [1926-1929]. Istoria literaturii române contemporane (1900-1937). Editura Fundației Naționale pentru Știință și Artă, 2015.

Modoc, Emanuel. Internaționala periferiilor. Rețeaua avangardelor în Europa Centrală şi de Est. Muzeul Literaturii Române, 2020.

Modoc, Emanuel et al. "Geografia romanului românesc (1901-1932): arealul national." Transilvania, no. 10, 2020: 12-21.

Modoc, Emanuel, and Daiana Gârdan. "Style at the Scale of the Canon. A Stylometric Analysis of 100 Romanian Novels Published between 1920 and 1940”. Metacritic Journal for Comparative Studies and Theory, 6.2, 2020: 48-63: https://doi.org/10.24193/mjcst.2020.10.03.

Manolescu, Nicolae. Istoria critică a literaturii române: 5 secole de literatură. București, Cartea Românească, 2019.

Moretti, Franco. "Network Theory, Plot Analysis." Literary Lab Pamphlet 2, May 1, 2011, https://litlab.stanford.edu/LiteraryLabPamphlet2.pdf.

Neagu, Laurentiu-Marian, et al. "A Quantitative Analysis of Romanian Writers' Demography Based on the General Dictionary of Romanian Literature”. Ludic, Codesign and Tools Supporting Smart Learning Ecosystems and Smart Education, 
Smart Innovation, Systems and Technologies 197, edited by Ó. Mealha et al., 253261. https://doi.org/10.1007/978-981-15-7383-5_22

Parvulescu, Anca, and Manuela Boatcă. "(Dis)Counting Languages: Between Hugo Meltzl and Liviu Rebreanu." Journal of World Literature 5, no.1, 2020: 47-78.

Parvulescu, Anca, and Manuela Boatcă. "The Inter-Imperial Dowry Plot.” Interventions. DOI: 10.1080/1369801X.2020.1762693.

Parvulescu, Anca, and Manuela Boatcă. “The longue durée of Enslavement: Extracting Labor from Romani Music in Liviu Rebreanu's Ion." Literature Compass 17, no. 12, 2020. Accessed November 15, 2020: https://doi.org/10.1111/lic3.12559.

Pojoga, Vlad et al. "Digital Tools for the Analysis of the Romanian Novel." Transilvania, no. 10, 2019: 9-16.

Pojoga, Vlad. "The Change of Medium and the Medium that Changes. Narrative Literature, Networks, and the Digital." Transylvanian Review vol. 28, Supplement 1, 2019: 203-215.

Raicu, Lucian. Liviu Rebreanu. Editura pentru Literatură, 1967.

Rebreanu, Liviu. Ion. Editura Eminescu, 1970.

---. Ion. Translated by A. Hillard, Peter Owen, 1965.

---. “Mărturisiri." Revista Fundaţiilor Regale, noiembrie 1940: 243-261.

Rogozanu, Costi. "10o de ani de când a fost publicat. De ce a ajuns Ion, de Liviu Rebreanu, cel mai citit și cel mai prost înțeles roman din literatura română.” Libertatea, November 22, 2020. Online at https://www.libertatea.ro/opinii/de-cea-ajuns-ion-de-liviu-rebreanu-cel-mai-citit-si-cel-mai-prost-inteles-roman-dinliteratura-romana-si-de-ce-cred-ca-e-cazul-sa-puneti-din-nou-mana-pe-el3272966.

Ryan, Marie-Laure. "Story/Worlds/Media: Tuning the Instruments of a MediaConscious Narratology." Storyworlds Across Media: Toward a Media-Conscious Narratology, edited by Marie-Laure Ryan and Jan-Noël Thon. University of Nebraska Press, 2014: 25-49.

Simion Cosma, Valer. "Inventing the Romanian Peasant in Transylvania during the Nineteenth Century.” Ruralism and Literature in Romania, edited by Ștefan Baghiu, Vlad Pojoga, Maria Sass, Peter Lang, 2019: 165-191. 
Taylor, Matthew. "[Re]-Visualizing the Novel." Media and Design Studio Blog, Weinberg College of Arts and Sciences, Northwestern University, 2015, http://web.madstudio.northwestern.edu/re-visualizing-the-novel/.

Terian, Andrei. "Big Numbers: A Quantitative Analysis of the Development of the Novel in Romania." Transylvanian Review vol. 28, Supplement 1, 2019: 55-71.

Terian, Andrei. "Istoria literară și analiza cantitativă. Un studiu al pieței de carte actuale din România." Exploring the Digital Turn, edited by Anca-Diana Bibiri, Camelia Grădinaru, Emanuel Grosu, Andreea Mironescu and Roxana Patraş, Iaşi, Editura Universităţii “Al.I. Cuza", 2019: 33-43.

Terian, Andrei. "Liviu Rebreanu. Zoopoetics in a Rural Environment". Ruralism and Literature in Romania, edited by Ștefan Baghiu, Vlad Pojoga, Maria Sass, Peter Lang, 2019: 41-56.

Toma, Irina et al. "Emerging Patterns in Romanian Literature and Interactive Visualizations based on the General Dictionary of Romanian Literature”. In International Conference on Human-Computer Interaction (RoCHI2O2O), 2020: 91-103. Online: MatrixRom. 